\title{
Genetic variation in twenty Philippine traditional rice varieties
}

\author{
A. Y. Cantila* and A. J. R. Quitel
}

Philippine Rice Research Institute, Midsayap, Cotabato, Philippines

\begin{abstract}
The study of genetic variation (GV) in 20 Philippine traditional rice varieties (TRVs) were determined in grain morphology such as length (Gl), width (Gwd), and weight (Gwt), grain yield (Gy), and grain micronutrients such as copper $(\mathrm{Cu})$, iron (Fe), manganese (Mn) and zinc ( $\mathrm{Zn})$. Analysis of variance obtained highly significant GV among TRVs in all traits. The mean for Gl, Gwd, Gwt, Gy, Cu, Fe, Mn, and Zn contents was $8.56 \mathrm{~mm}, 2.8 \mathrm{~mm}, 20.01 \mathrm{~g}, 2.13 \mathrm{t} / \mathrm{ha}, 8.64 \mathrm{ppm}, 14.56 \mathrm{ppm}$, $20.79 \mathrm{ppm}$, and 30.26ppm, respectively. The micronutrients in TRVs followed an order as $\mathrm{Zn}>\mathrm{Mn}$ $>\mathrm{Fe}>\mathrm{Cu}$. For the correlation in traits, 11 pairs were significantly correlated; however, only $\mathrm{Mn}$ and $\mathrm{Zn}$ content in grains was positively and strongly correlated. Other significant pairs were either in

Received: 27 January 2019

Revised: 16 June 2019

Accepted: 01 July 2019 positive or negative and moderately correlated. Cluster analysis, on the other hand, revealed five clusters and showed distinct TRV in two clusters. In conclusion, the presence of higher grain micronutrient content in TRVs indicatesa better opportunity for breeders to determine parental genetic resource in breeding rice with high grain micronutrients.
\end{abstract}

DOI: https://doi.org/10.3329/bjsir.v55i1.46730

Keywords: Grain-related traits; Indigenous rice varieties; Grain micronutrients

\section{Introduction}

Rice is one of the Green Revolution's priority crops that had been called as the "global grain" since it is consumed about half of the world's population (FAO, 2013). Their intervention made a significant increment in world's crop production (Ortiz, 2011) and prevented uncontrollable global famines (Khush, 1999). From then on, high yielding rice varieties had been the most output in any rice research. Yield is the product of multiple effects of secondary traits (Yoshida, 1983). This means that yield increment can also be attained once genetic variation in secondary traits is fully understood. For instance, grain related traits were observed as the determinants of having good quality and quantity of grains (Shi et al., 2000; Iwata et al., 2010). Then, the more number, long and heavy grains will eventually lead to high yield. Grain related traits however are easily affected by the environment as stated by Cantila et al. (2017) on their research on evaluating rice types outside its natural environment in the Philippines. That is why rigid evaluation should be done on these traits to determine positive yield outcome. However, the full adoption of high-yielding varieties of cereal has resulted in a dramatic reduction in food diversity and micronutrient intake (Cakmak et al., 2010). Also, achieving high yields in research overlooked micronutrient concentration on crops' edible parts, leading to a little information on this aspect (Nube and Voortman, 2006). More than half of the world's population were affected by micronutrient deficiency dubbed as the "hidden hunger" (Khush et al., 2012). Micronutrients played a vital role in cellular and hormonal responses, signaling and functions (Guerrant et al., 2000; Kapil and Bhavna, 2008). The micronutrients accumulated in grains are also the internal traits that have importance to grain quality (Waters and Sankaran, 2011); examples of micronutrients are copper, iron, manganese and zinc. The study aimed to analyze genetic variation $(\mathrm{GV})$ in eight traits, determine correlation in traits, and identify clusters in the 20 traditional rice varieties (TRVs).

\section{Materials and methods}

The Genetic Resource Division of the Philippine Rice Research Institute (PhilRice), Central Experimental Station, Nueva Ecija provided the 20TRVs such as Awot, Azucena, Binatang, Camuros, Chumi-i-tinawon, C2, C22, Dinorado1, Dinorado2, Hinomay,Hinumay, Kalinayin, Kasagpi, Kutibos,Malan, Milbuen3, Milpal18, Palawan, Pututan, and Wag-wag as the experimental units in the study. 
The experimental units were laid out triplicates in randomized complete block design at PhilRice, Midsayap Experimental Station from May 4 to August 29, 2017. The cultural management including weeding, fertilizer application, and chemical application protected and developed the plants. After harvesting, threshing, winnowing and cleaning; the grains were gathered data. For each experimental unit, grain length (Gl) and width (Gwd) was measured by averaging 10 random seeds using Vernier caliper. Similarly, grain weight (Gwt) was measured by weighing 1000 grains while grain yield (Gy) was determined by using the standard evaluation for rice (IRRI, 2014). For micronutrient content analysis, $20 \mathrm{~g}$ of each experimental unit was analysed using atomic absorption spectrophotometer and its concentration [copper $(\mathrm{Cu})$, iron $(\mathrm{Fe})$, manganese $(\mathrm{Mn})$ and zinc $(\mathrm{Zn})]$ was determined using the methods described in previous report by $\mathrm{Xu}$ et al.(2015) at the University of Southern Mindanao Agricultural Research Center. STAR 2.01 (IRRI, 2014) provided the descriptive statistics and analysis of variance (ANOVA). XLStat. The correlation was computed following Pearson's coefficient, and cluster analysis following the agglomerative hierarchical on unweighted pair group method arithmetic average or UPGMA and Euclidean distance' coefficient.

\section{Results and discussion}

Importance of genetic variation

The pace of varietal development depends on the amount of GV identified in the germplasm (Kumbhar et al., 2015). The GV in eight traits was found highly significant in 20 TRVs with samples shown in Figure 1. The mean for Gl, Gwd, Gwt and Gy was $8.56 \mathrm{~mm}, 2.8 \mathrm{~mm}, 20.01 \mathrm{~g}$ and $2.13 \mathrm{t} / \mathrm{ha}$, respectively (Table I). These values were within the range of other rice research like Nurhasanah (2017) in Gl, Nirmaladevi et al. (2015) in Gwd, Cantila et al. (2017) and Ortuoste and Ortuoste (2014) in Gy. Gl, Gwd and Gwt are very important to rice since they have the direct relationship to grain's quality and quantity (Maji and Shaibu, 2012). $\mathrm{Cu}, \mathrm{Fe}, \mathrm{Mn}$ and $\mathrm{Zn}$ contents, on the other hand, had a mean of $8.64 \mathrm{ppm}, 14.56 \mathrm{ppm}, 20.79 \mathrm{ppm}$ and $30.26 \mathrm{ppm}$, respectively (Table I). The micronutrients in TRVs followed an order as $\mathrm{Zn}>\mathrm{Mn}>\mathrm{Fe}>\mathrm{Cu}$. The values of different micronutrients were in parallel to the values found by different research like Genc et al. (2001) and Depar et al. (2011) in $\mathrm{Cu}$, Frossard et al. (2000) and Gregorio et al. (2000) in Fe, Heinemann et al. (2005) in $\mathrm{Mn}$, and Genc et al. (2001), Graham et al. (1999) and Gregorio et al. (2000) in Zn. In plants, the leaves act as sink tissues where micronutrients are vital to photosynthesis

Table I. Eight traits' means, mean squares and coefficient of variation showing the significance of genetic variation

\begin{tabular}{|c|c|c|c|c|c|}
\hline \multirow[t]{2}{*}{ Traits } & \multirow[t]{2}{*}{ Mean \pm SE } & \multicolumn{3}{|c|}{ Mean Squares } & \multirow{2}{*}{ CV $(\%$} \\
\hline & & Replication & Genotype & Error & \\
\hline $\mathrm{Gl}(\mathrm{mm})$ & $8.56 \pm 0.25$ & 0.13 & $1.646^{* *}$ & 0.09 & 3.51 \\
\hline Gwd (mm) & $2.8 \pm 0.18$ & 0.06 & $0.2994 * *$ & 0.05 & 8.01 \\
\hline Gwt (g) & $20.01 \pm 1.6$ & 7.82 & $19.9342 * *$ & 3.84 & 9.8 \\
\hline Gy (t/ha) & $2.13 \pm 0.54$ & 0.57 & $1.9474 * *$ & 0.44 & 31.17 \\
\hline $\mathrm{Cu}(\mathrm{ppm})$ & $8.64 \pm 1.82$ & 30.42 & $54.29 * *$ & 4.98 & 4.3 \\
\hline $\mathrm{Fe}(\mathrm{ppm})$ & $14.56 \pm 2.05$ & 5.13 & $28.25^{* *}$ & 6.31 & 5.75 \\
\hline $\mathrm{Mn}(\mathrm{ppm})$ & $20.79 \pm 1.77$ & 35.18 & $74.8864 * *$ & 4.73 & 10.46 \\
\hline $\mathrm{Zn}(\mathrm{ppm})$ & $30.26 \pm 1.97$ & 14.20 & $72.0172 * *$ & 5.83 & 7.98 \\
\hline
\end{tabular}

Footnote: $\mathrm{SE}=$ standard error, ${ }^{* *}$ significant at $\mathrm{p}<0.001$ level, $\mathrm{CV}=$ coefficient of variation, $\mathrm{Gl}=$ grain length, Gwd=grain width, $\mathrm{Gwt}=$ grain weight, $\mathrm{Gy}=$ grain yield, $\mathrm{Cu}=$ copper, $\mathrm{Fe}=$ iron, $\mathrm{Mn}=$ manganese, and $\mathrm{Zn}=\mathrm{zinc}$. 


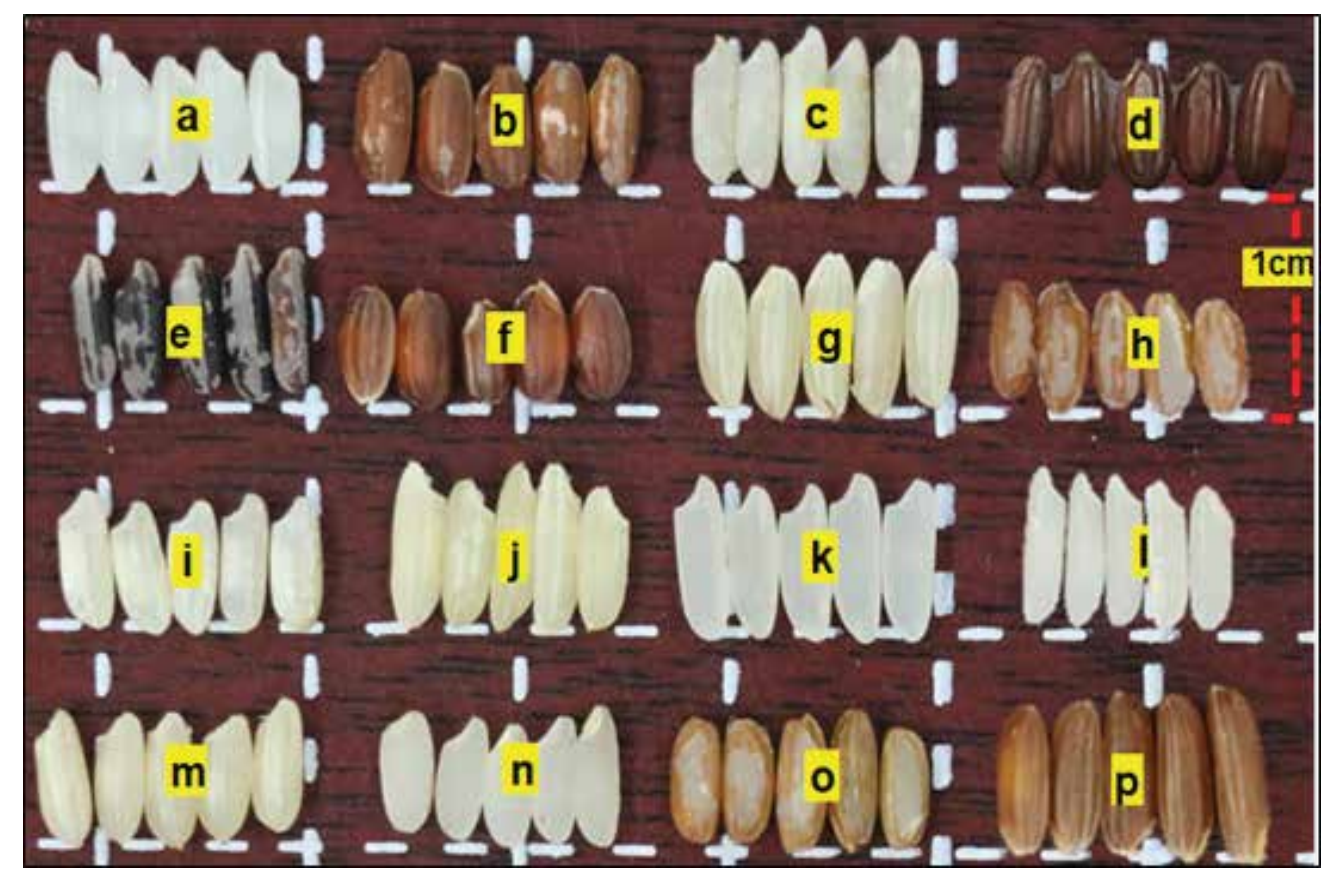

Fig. 1. Grain samples showing genetic variation

Legend: $\mathrm{a}=$ Camuros, $\mathrm{b}=$ Binatang, $\mathrm{c}=$ Chumi-i-tinawon, $\mathrm{d}=$ Palawan, $\mathrm{e}=$ Kasagpi $\mathrm{f}=$ Pututan, $\mathrm{g}=$ Hinomay, $\mathrm{h}=$ Kasagpi, $\mathrm{I}=$ Hinumay, $\mathrm{j}=$ Milbuen3, $\mathrm{k}=$ Azucena, $\mathrm{l}=$ Awot, $\mathrm{m}=$ Kalinayin, $\mathrm{n}=$ Dinorado1, $\mathrm{o}=$ Dinorado2 and $\mathrm{p}=$ Kutibos.

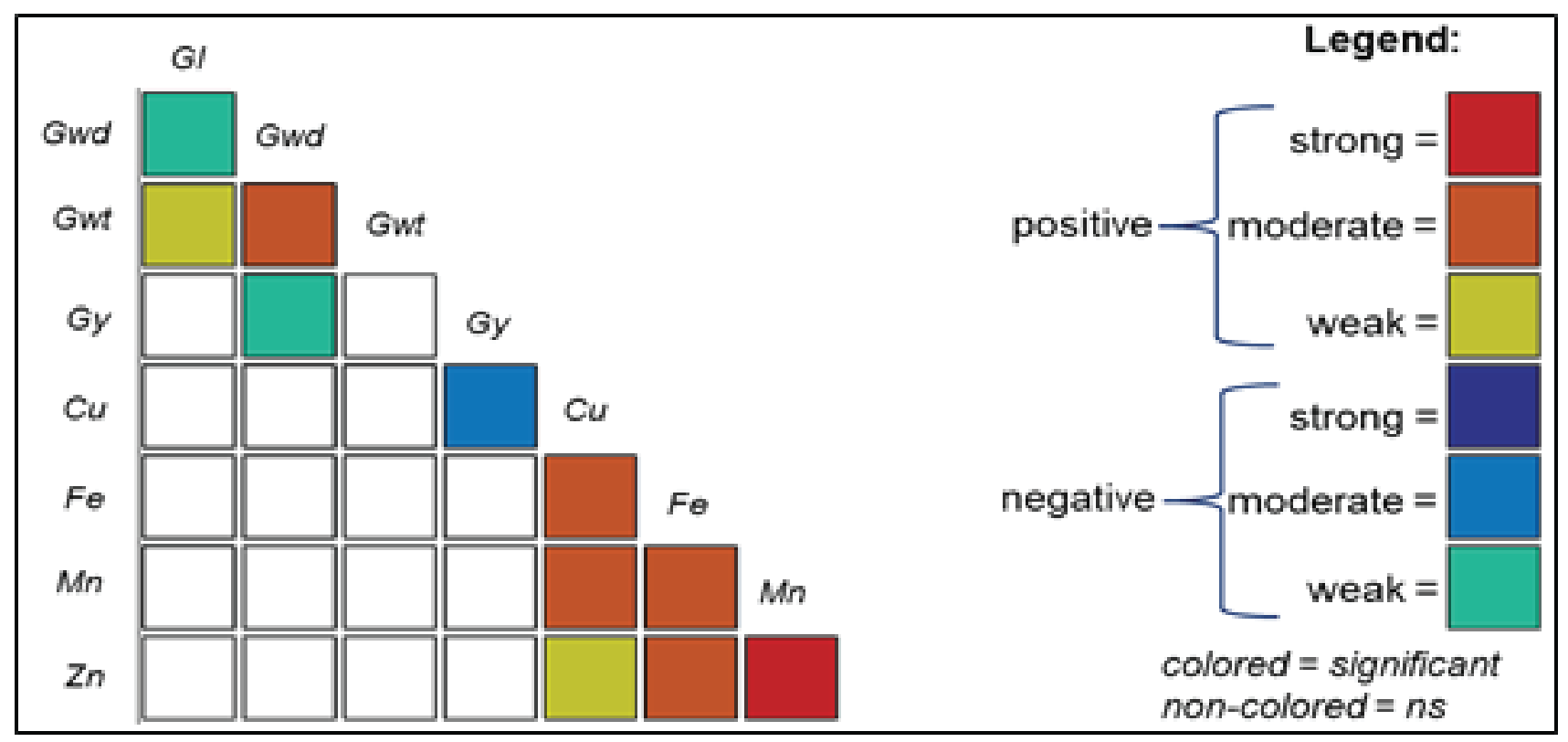

Fig. 2. Correlation analysis showed the relationship of the eight traits

Legend: $\mathrm{Gl}=$ grain length, $\mathrm{Gwd}=$ grain width, $\mathrm{Gwt}=$ grain weight, $\mathrm{Gy}=$ grain yield, $\mathrm{Cu}=$ copper, $\mathrm{Fe}=$ iron, $\mathrm{Mn}=$ manganese, and $\mathrm{Zn}=$ zinc. 
and other metabolic mechanism (Gupta et al., 2015). Plants transport micronutrients from the source tissues to edible seeds during the grain filling stage (Waters and Sankaran, 2011). The accumulation lies on its soil ion availability, root uptake efficiency, shoot translocation, and seeds' storage (Grusak 1999; Olsen and Palmgren, 2014). Micronutrients in the grains is important to humans since $\mathrm{Cu}$ deficiency leads to skeletal defects, Fe deficiency leads to anemia, Mn deficiency leads to tremors and stiff muscles and $\mathrm{Zn}$ deficiency leads to dwarfness and infertility (Sebastian and Prasad, 2015). GV based on grains, therefore, is vital for rice research.

\section{Correlation in traits}

Pearson correlation analysis identified the relationship between eight traits. Taylor (1990) identified correlation as follows: weak if $\mathrm{r}=0.01-0.35$, moderate if $\mathrm{r}=0.36-0.67$ and strong if $r=0.68-0.99$. Cantila and Quitel (2017) applied this implication in their rice research on foreign genotypes Only
11 significant pairs, however, were obtained with 8 pairs in positive and 3 pairs in negative correlation (Figure 2). Positive and strong correlation was found between $\mathrm{Mn}$ and Zn contents, positive and moderate between Gwd and Gwt, $\mathrm{Fe}$ and $\mathrm{Zn}$ contents, $\mathrm{Fe}$ and $\mathrm{Cu}$ contents, $\mathrm{Fe}$ and $\mathrm{Mn}$ contents and, $\mathrm{Cu}$ and $\mathrm{Mn}$ contents, and negative and moderate between $\mathrm{Gy}$ and $\mathrm{Cu}$ content (Figure 2). Among the trait pairs based on grain morphology, only Gl and Gwt was positive and significantly correlated while the rest was in weak or not significantly correlated. Not enough information is available about micronutrient accumulation in relation to an increased yield or biomass (Xue et al. 2014). The negative relationship of yield and $\mathrm{Cu}$ content has been pointed out by Garvin et al. (2006) and Murphy et al. (2008) that high grain yields may lead to a decrease of micronutrients in the grains. On the other hand, it was noted that all micronutrients were positively correlated to each other. Roberts et al. (2004) reported that phytosiderophores, an amino acid synthesized and released

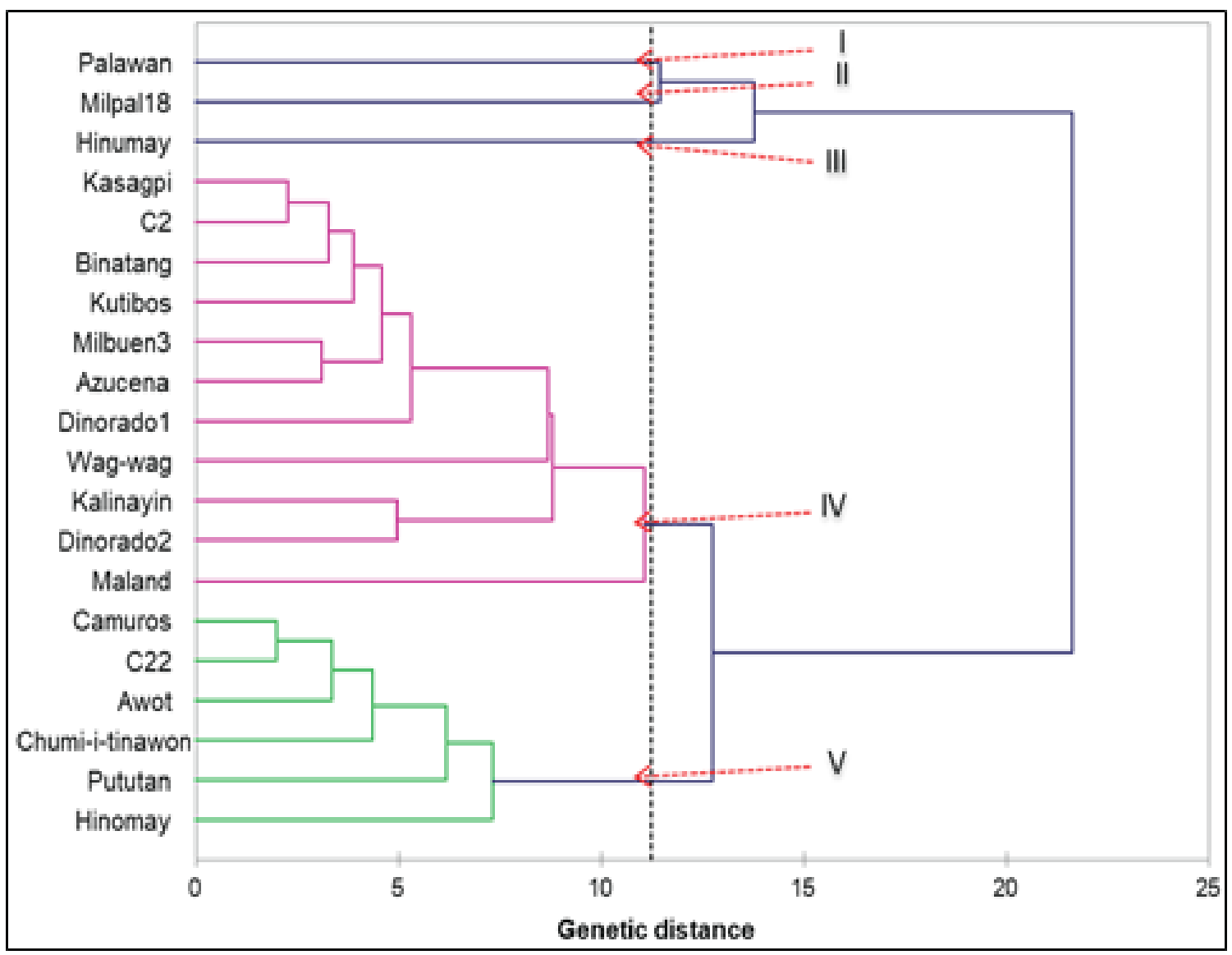

Fig. 3. Clustering of $20 \mathrm{TRV}$ s based on the eight traits 
Table II. Mean values of TRVs in eight traits

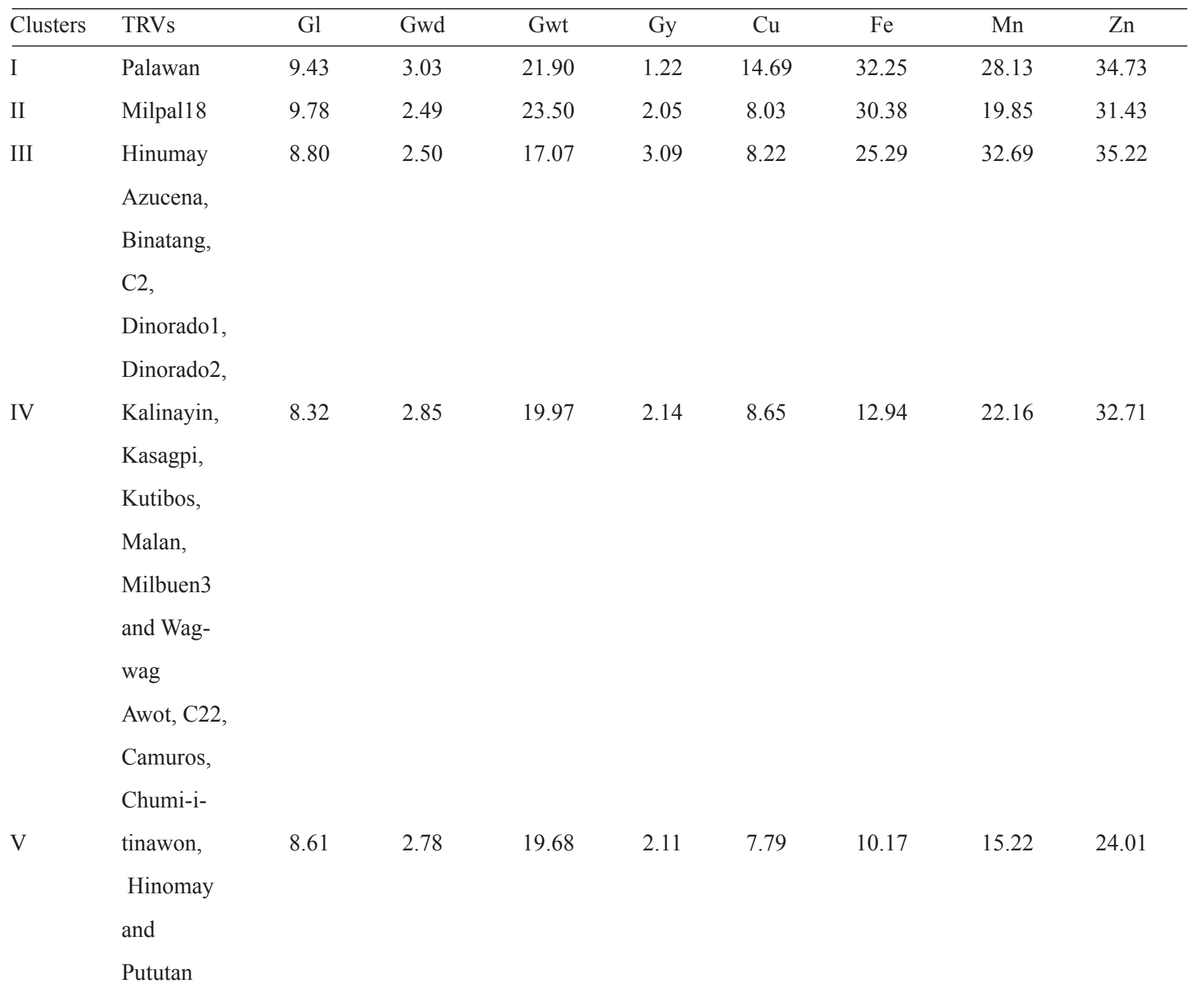

Footnote: $\mathrm{Gl}=$ grain length, $\mathrm{Gwd}=$ grain width, $\mathrm{Gwt}=$ grain weight, $\mathrm{Gy}=$ grain yield, $\mathrm{Cu}=$ copper, $\mathrm{Fe}=$ iron, $\mathrm{Mn}=$ manganese, and $\mathrm{Zn}=\mathrm{zinc}$.

by gramene monocots, chelate Fe and forms a stable Fe. This interaction then leads to the translocation of $\mathrm{Zn}, \mathrm{Cu}$ and $\mathrm{Mn}$ across the plant cell (Ueno et al., 2009). The relationship result especially between micronutrients suggests that increasing all micronutrients in a grain can be done in one variety.

\section{Clusters in TRVS}

The genetic distance, Euclidean values, of the 20 TRVs was computed using eight traits. Euclidean values were ranged from 2.0 to 30.5 among 190 pairs of TRVs (Figure 3). Among the TRVs, Camuros and C22 are the closest with 2.0, followed by $\mathrm{C} 2$ and Kasagpi with 2.3 and Awot and Camuros with 2.5 (Figure 3). In contrast, the farthest pairs were in $\mathrm{C} 2$ and Palawan with 30.5 , Camuros and Palawan with 29.3 and Awot and Palawan with 29.0 (Figure 3) indicating high genetic difference between paired TRVs. Breeding Palawan to C2, Camuros or Awot may give offsprings with high genetic variation. However, analysis showed five clusters. Cluster IV had 11 TRVs while cluster V had 6 TRVs (Figure 3; Table II). The means 
in Gl (8.32mm), Gwd (2.85mm), Gwt (19.97g) and Gy $(2.14 \mathrm{t} / \mathrm{ha})$ of cluster IV members were much nearer to the overall means (Table I). On the other hand, the mean in $\mathrm{Cu}$, $\mathrm{Fe}, \mathrm{Mn}$ and $\mathrm{Zn}$ contents of cluster $\mathrm{V}$ members were the lowest. Another, clusters I, II and III had Palawan, Milpal18 and Hinumay, respectively. Unique membership can be due to its highest values observed in a TRV. Palawan in cluster I had the highest values in Gwd with $3.03 \mathrm{~mm}, \mathrm{Cu}$ content with $14.69 \mathrm{ppm}$ and $\mathrm{Fe}$ content with $32.25 \mathrm{ppm}$ (Table II). Milpal18 in cluster II had the highest values in Gl with $9.078 \mathrm{~mm}$ and Gwt with $23.5 \mathrm{~g}$ (Table II). Hinumay in cluster III had the highest values in Gy, Mn and $\mathrm{Zn}$ with $3.09 \mathrm{t} / \mathrm{ha}, 32.69 \mathrm{ppm}$ and $35.22 \mathrm{ppm}$, respectively (Table II). Two out of three clusters (I and III) with unique membership and Cluster $\mathrm{V}$ had their grouping as a result of varying grain nutrient contents. Micronutrients are indeed variable in rice, indicative of better opportunity for breeders to select genotypes as parents for increasing micronutrients in rice grains.

\section{Conclusion}

High significant variation in $20 \mathrm{TRVs}$ was obtained throughout the eight traits while 11 significant correlations were found in 28 pairs among traits. It was noted that micronutrients' relationship was significantly positive, result imply that increasing micronutrients in a grain is achievable.

\section{Acknowledgment}

The authors would like to express their gratitude to Mr. Elmer F. Bedia, field laborer of the study and to the staff and management of PhilRice, Midsayap Experiment Station, Bual Norte, Midsayap, Cotabato.

\section{References}

Cakmak I, Kalayci M, Kaya Y, Torun A, Aydin N and Wang, Y (2010), Biofortification and localization of zinc in wheat grain, Journal of Agricultural and Food Chemistry 58: 9092-9102.

Cantila AY, Abdula SE and Balos J (2017), Morphometric analysis of upland rice phenotypes in lowland condition, Journal of Biodiversity and Environmental Sciences 10(4): 62-69.

Cantila AY and Quitel AJR (2017), Statistical Analysis of Foreign Rice Phenotypes under Different Seasons of the Philippines, Journal of Advanced Applied Scientific Research 12(1): 7.
Depar N, Rajpar M, Memon M and Ulhassan Z (2011), Mineral nutrient densities in some domestic and exotic rice genotypes. Pakistan Journal of Agriculture, Agricultural Engineering and Veterinary Sciences 27: 134-142.

FAO (2013), FAO statistical yearbook, World food and agriculture, Food and Agriculture Organization of the United Nations, Rome.

Frosard E, Bucher M, Machler F, Mozafar A and Hurrell R (2000), Potential for increasing the content and bioavailability of $\mathrm{Fe}, \mathrm{Zn}$ and $\mathrm{Ca}$ in plants for human nutrition, Journal of the Science of Food and Agriculture 80: 861-879.

Garvin D, Welch R and Finley J (2006), Historical shifts in the seed mineral micronutrient concentrations of US hard red winter wheat germplasm, Journal of the Science of Food and Agriculture 86: 2213-2220.

Genc H, Ozdemir M. and Demirbas A (2001), Analysis of mixed-linked $(1 \rightarrow 3)(1 \rightarrow 4) \beta$-D-glucans in cereal grains from Turkey, Food Chemistry 73: 221-224.

Graham R, Senadhira D, Beebe S, Iglesias C and Monesterio I (1999), Breeding for micronutrient density in edible portions of stable food crops: Conventional crops approaches, Field Crops Research 60(1-2): 57-80. DOI: 10.1016/ S0378-429(98)00133-6.

Gregorio G, Senadhira D, Htut H and Graham R (2000), Breeding for trace mineral density in rice, Food and Nutrition Bulletin 21: 382-386.

Grusak M and Penna D (1999), Improving the nutrient composition of plants to enhance human nutrition and health, Annual Review of Plant Physiology and Plant Molecular Biology 50(1): 133-61.

Guerrant R, Lima A and Davidson F (2000), Micronutrients and infection: interactions and implications with enteric and other infections and future priorities, Journal of Infectious Diseases 182: 134-138.

Gupta H, Hossain F, Nepolean T, Vignesh $M$ and Mallikurjana M (2015), Bases of $\mathrm{Fe}$ and $\mathrm{Zn}$ Accumulation Towards Development of Micronutrient-Enriched Maize In: Nutrient Use Efficiency: from Basics to Advances, Ed. Rakshit A, Springer India, pp 255-282. 
Heinemann R, Fagundes P, Pinto E, Penteado $M$ and Lanfer-Marquez U (2005), Comparative study of nutrient composition of commercial brown, parboiled and milled rice from Brazil, Journal of Food Composition and Analysis 18: 287-296. DOI: 10.1016/j.jfca.2004.07.005.

IRRI (International Rice Research Institute) (2014), Standard Evaluation System for rice (SES), $5^{\text {th }} \mathrm{Ed}$. Los Baños, Laguna, Philippines.

Iwata H, Ebana K, Uga Y, Hayashi T and Jannink J (2010), Genome wide association study of grain shape variation among OryzasativaL. germplasm based on elliptic Fourier analysis, Molecular Breeding 25: 203-215.

Kapil U and Bhavna A (2008), Adverse effects of poor micronutrient status during childhood and adolescence, Nutrition Reviews 60: S84-S90

Khush GS (1999), Green revolution: preparing for the $21^{\text {st }}$ century, Genome 42: 646-655.

Kumbhar S, Kulwal P, Patil J, Sarawate C, GaikwadA and Jadhav A (2015), Genetic Diversity and Population Structure in Landraces and Improved Rice Varieties from India, Rice Science 22(3): 99-107. DOI: 10.1016/j.rsci.2015.05.013

Khush G, Lee S, Cho J and Jeon J (2012), Biofortification of crops for reducing malnutrition, Plant Biotechnology Reports. DOI: 10.1007 /s11816-012-0216-5

Maji A and Shaibu A (2012), Application of principal component analysis for rice germplasm characterization and evaluation, Journal of Plant Breeding and Crop Science 4(6): 87-93.

Murphy K, Reeves P and Jones S (2008), Relationship between yield and mineral nutrient concentrations in historical and modern spring wheat cultivars, Euphytica 163: 381-390.

Nirmaladevi G, Padmavathi G, Suneetha K and Babu V (2015), Genetic variability, heritability and correlation coefficients of grain quality characters in rice (Oryza sativa L.), SABRAO Journal of Breeding and Genetics 42(4): 424-433.

Nube $M$ and Voortman R (2006), Simultaneously addressing micronutrient deficiencies in soils, crops, animal and human nutrition: opportunities for higher yields and better health, Centre for World Food Studies, Amsterdam, The Nederlands, Staff Working Paper, WP06-02. P48

Nursahanah S (2017), Yield-related traits characterization of local upland rice cultivars originated from East and North Kalimantan, Indonesia. Biodiversitas 18(3): 1165-1172.

Olsen L and Palmgren M (2014), Many rivers to cross: the journey of zinc from soil to seed, Frontiers in Plant Science 5: 30. DOI: 10.3389/fpls.2014. 00030

Ortiz R (2011), Re-visiting the green revolution, Chronica Horticulture 51: 6-11. DOI: 10.1016/j. scienta.2011.09.020

Ortuoste R and Ortuoste J (2014), Testing and Evaluation of Upland Rice Varieties in Sultan Kudarat Province. International Conference on Biological, Civil and Environmental Engineering (BCEE-2014) March 17-18, Dubai (UAE),

Roberts L, Pierson A, Panaviene Z and Walker E (2004), Yellow Stripe1 expanded roles for the maize iron-phytosiderophore transporter, Plant Physiology 135: $115-120$

Sebastian A and Prasad MNV (2015), Trace Element Management in Rice, Agronomy 5: 374-404.

Shi C, Zhu J, Wu J and Fan L (2000), Genetic and genotype $\mathrm{x}$ environment interaction effects from embryo, endosperm, cytoplasm and maternal plant for rice grain shape traits of indicarice, Field Crops Research 68: 191-198.

Taylor R (1990), Interpretation of the correlation coefficient: A basic review, Journal of Diagnostic Medical Sonography 6: 35-39.

Ueno D, Yamanji N and Ma J (2009), Further characterization of ferric-phytosiderophore transporters ZmYS1 and HvYS1 in maize and barley, Journal of Experimental Botany 60: 3513-3520.

Waters B and Sankaran R (2011), Moving micronutrients from the soil to the seeds: genes and physiological processes from a biofortification perspective, Plant Science 180: 562-574. DOI: 10.1016/j. plantsci. 2010.12.003.

Xue Y, Yue S, Zhang W, Liu D, Cui Z, Chen X, Ye Y and Zou C (2014), Zinc, Iron, Manganese and Copper 
Uptake Requirement in Response to Nitrogen Supply and the Increased Grain Yield of Summer Maize, PloS one 9.e93895. DOI: 10.1371/ journal.pone.0093895.

Xu Q, Zheng TQ, Hu X, Cheng LR, Xu JL and Shi YM (2015), Examining two sets of introgression lines in rice (Oryzasativa L.) reveals favorable alleles that improve grain $\mathrm{Zn}$ and $\mathrm{Fe}$ concentrations, PLoS one DOI: 10:e0131846. 10.1371/journal.pone.0131846.
Yoshida S (1983), Rice in 'Potential productivity of field crops under different environments' Eds. Smith WH and Banta SJ, International Rice Research Institute Publishing, Los Baños, Philippines, pp 103-127.

Zeng Y, Zhang H, Wang L, Pu X, Du J, Yang S and Liu J (2010), Genotypic variation in element concentrations in brown rice from Yunnan landraces in China, Environmental Geochemistry and Health 32: 165-177. 